\title{
Nasjonale registerkilder i epidemiologisk forskning
}

\author{
Siri E. Håberg ${ }^{1}$, Marta Ebbing $^{1}$ og Camilla Stoltenberg ${ }^{1,2}$ \\ ${ }^{I}$ Folkehelseinstituttet, Oslo og Bergen \\ ${ }^{2}$ Universitetet $i$ Bergen \\ sirieldevik.haberg@fhi.no
}

This is an open access article distributed under the Creative Commons Attribution Licence, which permits unrestricted use, distribution, and reproduction in any medium, provided the original work is properly cited.

\section{INTRODUKSJON}

I Norge har vi nasjonale personregistre med informasjon om demografi, familier, sosiale forhold, helseopplysninger og helsetjenester. I tillegg er nesten en million personer med i befolkningsbaserte helseundersøkelser, og mange hundre tusen blodprøver er lagret til forskningsformål. De nasjonale registrene er opprettet for mange ulike formål, og er verdifulle datakilder for forskning. Fødselsnummeret inngår i nesten alle registre, og data fra de ulike registrene kan derfor kobles. Vi har dermed nasjonale data som kan brukes til å beskrive og studere helse og sykdom for hele befolkningen, og gjennom hele livsløpet. Utenom Norden er det få land som har tilsvarende muligheter. I helseundersøkelser og andre typer studier er man avhengig av å rekruttere deltagere. Det kan være vanskelig å oppnå utvalg med samme demografiske og sosioøkonomiske sammensetning som befolkningen ellers. Enkelte grupper kan være spesielt vanskelige å rekruttere, og noen problemstillinger vil være uetiske å studere. Dette gjelder for eksempel studier av legemiddelvirkninger og bivirkninger, og sikkerhet av vaksiner hos gravide og barn. Kobling av informasjon fra nasjonale registre har vist seg svært nyttige i studier som bidrar til slik kunnskap ${ }^{1-3}$. Alvorlig psykisk syke personer, personer med utviklingshemning, sosialt usatte grupper og eldre med funksjonsnedsettelse kan også være vanskelige å rekruttere til helseundersøkelser og forskningsprosjekter som forutsetter informert samtykke. I registerbasert forskning kan vi bruke informasjon som er hentet rutinemessig fra helsetjenestene og samfunnet til nasjonale registre, og kombinere opplysninger om helse og sykdom gjennom livsløpet med data om demografiske og sosioøkonomiske forhold som landbakgrunn, sivil status, familieforhold, og utdanning. Landsdekkende registre med helsedata fra fødsel til død, oversikt over familiære relasjoner og muligheten til å bruke registerinformasjon sammen med data fra helseundersøkelser eller andre kohortstudier og tilknyttede biobanker, gir unike forskningsmuligheter $^{4-11}$. Slike koblinger gir mulighet til å studere risikofaktorer som ikke registreres i nasjonale registre, som for eksempel genetikk, miljø- og livsstilsfaktorer, og lettere symptomer og tilstander som ikke behandles eller registreres i helsetjenestene. Mulighetene vi har i Norge gjør at vi kan bidra til å øke kunnskapsgrunnlaget internasjonalt, og de giør at vi er attraktive samarbeidspartnere for verdensledende forskningsmiljøer.

\section{MEDISINSK FØDSELSREGISTER - ET UNIKT UTGANGPUNKT}

Medisinsk fødselsregister (MFR) er det eldste fødselsregisteret i verden - og vi mener det også er et av de beste $i$ verden. Kobling av MFR med andre datakilder gir mulighet til å studere forhold knyttet til graviditet, fødsel, barsel og barn som ellers er vanskelig eller umulig. Randomiserte kontrollerte studier inkluderer sjelden kvinner i fertil alder, og nesten aldri gravide eller barn. For eksempel kan man koble MFR-data med data fra Reseptregisteret og få kunnskap om legemiddelbruk hos gravide, og undersøke sikkerheten ved mors legemiddelbruk også for barnet ${ }^{12}$. MFR er sentral også i koblinger med andre registre og kohortstudier, og flere artikler i de mest prestisjetunge tidsskriftene $\mathrm{i}$ verden er basert på slike koblinger med MFR og andre datakilder ${ }^{2,11}$.

Fødselsregisterdata gir nyttige bidrag i studier av gjentagelsesrisiko for uheldige svangerskapsutfall og det norske registeret har unike data, for eksempel om hvordan avvikende navlesnorsfeste øker risiko for uheldige svangerskapsutfall ${ }^{13,14}$.

Svangerskap og fødsel er nært knyttet til barnas helse og risiko for sykdom. Koblinger av data fra MFR, Reseptregisteret og Norsk pasientregister har økt kunnskapen om sammenhengen mellom svangerskap, fødselsutfall og helse senere i livet ${ }^{15-19}$. For eksempel er fødselsvekt, for tidlig fødsel og assistert befruktning knyttet til helse og utvikling hos barn ${ }^{15,18-21}$.

Informasjon i MFR gir også mulighet til å følge kvinners risiko for svangerskapskomplikasjoner $\mathrm{i}$ hennes ulike svangerskap, og hvordan svangerskapstilstander kan ha sammenheng med sykdom senere i livet ${ }^{17,19,22}$. Det er for eksempel vist at kvinner som har gjennomgått assistert befruktning kan ha økt risiko for $\mathrm{kreft}^{23}$, og man kan studere risiko for uheldige svangerskaps- og fødselskomplikasjoner og mulige sammenhenger med skifte av partner, og om det er tid mellom svangerskap eller andre faktorer som spiller $i^{24-26}$. Det er også gjennomført studier som viser at forhold i svangerskapet har sammenheng med senere hjertesykdom, kardiovaskulær død og diabetes ${ }^{27,28}$.

Dersom man vil undersøke risiko for relativt sjeldne hendelser eller eksponeringer er det nødvendig med store studiepopulasjoner. Det er etablert flere samarbeidsprosjekter mellom de nordiske landene som gjør det mulig å studere sjeldne eksponeringer og utfall $^{21,29-32}$ 


\section{GENERASJONSSTUDIER, LIVSLØPSSTUDIER OG KOMORBIDITET}

Gjennom bruk av data fra Folkeregisteret sammen med helseregisterdata er det mulig å studere familiær opphopning av sykdommer og andre risikofaktorer ${ }^{32-34}$, noe som er unikt i internasjonal sammenheng. Det er stort behov for flere studier om underliggende familiær risiko for sykdommer, legemiddelbruk, og risikofaktorer $^{5,22}$. Ved bruk av statistiske tilnærminger som for eksempel søskenanalyser er det mulig å redusere effekten av skjevheter forårsaket av uobserverte felles faktorer $^{35-37}$.

Det har vært en økende interesse for hvordan påvirkninger og utvikling $\mathrm{i}$ fosterlivet og $\mathrm{i}$ tidlige livsfaser har betydning for senere helse og risiko for sykdom $^{38-41}$. Biologiske mekanismer er identifisert ${ }^{42}$, og det er hypoteser om at miljøpåvirkninger kan ha en betydning for genetiske faktorer som påvirker risiko for sykdommer og at det skjer varige endringer av risiko knyttet til tidlige eksponeringer ${ }^{43}$. Studier basert på data fra MFR har bidratt til slik forskning ${ }^{44,45}$.

Det er også i økende grad forståelse for at det er viktig å studere det kompliserte samspillet mellom ulike sykdommer for å forstå utvikling og forløp. I klinikken er dette samspillet mellom sykdomstilstander og symptomer en del av hverdagen, mens epidemiologiske studier kan bli bedre ved å inkludere bredere informasjon om komorbiditet, sykdomsforløp, og behandlingsforløp. For eksempel er det ikke uvanlig at eldre pasienter kan ha både kardiovaskulær sykdom, diabetes og lungesykdom, og i tillegg ha psykisk sykdom som depresjon eller demens. Legemiddelbruk, behandling og sykdommer bør studeres i sammenheng, og dette er noe registerdata kan bidra til ${ }^{46}$. Registerdata kan også gi oss økt innsikt i immunologiske tilstanders betydning i utvikling av andre sykdommer ${ }^{47}$.

\section{SÅRBARE GRUPPER OG SOSIAL ULIKHET I HELSE}

Det er samspill mellom sosiale og biologiske faktorer $i$ utbredelse og utvikling av sykdom, og i helse- og sykdomsatferd. For å kunne identifisere risikogrupper er det nødvendig med mer kunnskap om betydningen av sosiale faktorer i helse og sykdom. Informasjon fra MFR har vist at sosiale og demografiske faktorer spiller en rolle for risiko hos gravide ${ }^{48-50}$, og for barnets senere helse ${ }^{51}$. Det er viktig å øke kunnskapen om underliggende risikofaktorer og familiær opphopning av risikofaktorer og sykdom. Økt kunnskap om hvordan både genetiske og sosiale faktorer spiller inn $\mathrm{i}$ overføring av risikofaktorer og helse mellom generasjoner, og samspillet mellom demografiske, sosiale og biologiske risikofaktorer vil kunne bidra til bedre planlegging og gjennomføring av forebyggende tiltak, og en mer effektiv og målrettet ressursbruk. Registerstudier bidrar til slik kunnskap og har blant annet vist at ADHD diagnostiseres oftere hos barn som er yngst $i$ sitt årskull, og at noen innvandrergrupper har økt forekomst av obstetriske komplikasjoner ${ }^{52,53}$.

\section{SVAKHETER VED REGISTERDATA OG KOBLINGER}

Registerdata er som nevnt ofte generert med flere formål enn forskning. Informasjonsmodellen og datakvaliteten i ulike registre bør diskuteres og vurderes for hvert problemstilling ${ }^{54,55}$. Informasjonen som finnes i fødselsregisteret er vurdert for flere tilstander, og det er utfordringer knyttet til hvor korrekt informasjonen er, samtidig som mye av informasjonen har høy kvalitet ${ }^{56-59}$. Ulik oppfølgingstid i ulike registre kan også by på utfordringer og må tas hensyn til i studier med koblete data. Det er likevel uten tvil stor nytteverdi av registerdata i forskning. Kjennskap til registreringsrutiner og praksis, dataflyt og dataforvaltning er viktig, og i studier med bruk av ulike helseregistre er det ofte fornuftig med samarbeid mellom epidemiologer, statistikere, klinikere, brukere og registerforvaltere som kjenner registrene godt, for å identifisere kunnskapsbehovene, definere gode problemstillinger og utføre analyser av høy kvalitet.

\section{PERSONVERN, SIKKERHET OG ETIKK}

For å kunne bruke helseopplysninger og informasjon om familiære forhold, sosioøkonomiske forhold, og risikofaktorer som finnes i registre og helseundersøkelser, er det en forutsetning at befolkningen har tillit til at opplysningene oppbevares trygt og at personvernet og sikkerheten ivaretas $i$ all forskning med slike data $^{60}$. I registerstudier har forskerne som regel ikke tilgang til direkte personidentifiserende kjennetegn (som navn eller fødselsnummer) men bruker prosjektspesifikke løpenummer. Vi kan bli flinkere til å kommunisere at vi i slik forskning ikke studerer enkeltindividers risiko, men risiko i grupper av befolkningen, og at det er nødvendig med en viss størrelse på gruppene for at resultater skal være informative. Nytteverdien av å bruke allerede innsamlede registerdata til forskning bør kommuniseres tydeligere til befolkningen og politikere slik at samfunnets nytte av slik forskning kommer klart frem. Norge og Norden har best kunnskap om datagrunnlaget og et ansvar for å gjøre gode studier med data fra nasjonale registre og datakilder.

\section{UTFORDRINGER}

Økt bruk av registerdata fra forvaltning og helsetjenesten til forskning vil redusere behovet for innsamling av data direkte fra befolkningen eller pasientene. Forskning og helseanalyser må øke kunnskap om hvem som blir syke, hvor mange som blir syke, årsaker til sykdom og tidlig død, og hvordan man kan forebygge sykdom og fremme god helse for hele befolkningen.

Norske data er en viktig ressurs i internasjonal forskning, men det er fortsatt unødig ressurskrevende å utføre norske og nordiske registerstudier ${ }^{61}$. Økende datamengder og et komplisert system for forvaltning av data er en utfordring for utnyttelsen av nasjonale registerdata $^{62,63}$. Det er økende engasjement og forståelse for at det er behov for å videreutvikle sikre syste- 
mer og forenkle byråkratiet rundt tilgang til helsedata. Vi ser frem til at arbeidet som nå er satt $i$ gang for å lette tilgangen til helsedata for alle legitime formål, herunder forskning, skal føre til forbedringer ${ }^{64}$. Helsedatautvalgets rapport er på høring ${ }^{63}$, og arbeidet $i$ Helsedataprogrammet hos Direktoratet for e-helse er $\mathrm{i}$ gang $^{65}$. Forskersamfunnet bør engasjere seg i prosessene slik at arbeidet ikke stanser opp og resultatet blir godt.

\section{KONKLUSJON}

Ved å koble data fra ulike nasjonale registre har forskere i Norge et unikt utgangspunkt for studier som svært få andre land kan gjennomføre. Med dette privilegiet følger et ansvar for at vi utnytter datakildene godt. I fødselsregisterets 50 år lange historie er det mange eksempler både på grensesprengende og nyttig forskning, og ikke minst gjelder dette der fødselsregisterdata er koblet til andre registre og datakilder. Respekt for personene som bidrar med informasjon til registrene er en forutsetning for tillit til registrene og forskningsmiljøene. I tillegg til å etterstrebe høy kvalitet, nytte og nyskaping i forskningen, må vi som bruker registerdata være gode til å formidle forskningen slik at den kan komme hele befolkningen til gode og bidra til vitenskapelig kunnskap i Norge og internasjonalt.

\section{REFERANSER}

1. Ruiz PL, Stene LC, Gulseth HL, et al. Pandemic influenza A H1N1 vaccination and subsequent risk of type 1 diabetes in Norway. Epidemiology 2017, doi: 10.1097/EDE.0000000000000748.

2. Håberg SE, Trogstad L, Gunnes N, et al. Risk of fetal death after pandemic influenza virus infection or vaccination. $N$ Engl J Med 2013; 368 (4): 333-40.

3. Trogstad L, Bakken IJ, Gunnes N, et al. Narcolepsy and hypersomnia in Norwegian children and young adults following the influenza A(H1N1) 2009 pandemic. Vaccine 2017; 35 (15): 1879-85.

4. Egeland GM, Klungsøyr K, Øyen N, Tell GS, Næss O, Skjærven R. Preconception cardiovascular risk factor differences between gestational hypertension and preeclampsia: Cohort Norway Study. Hypertension 2016; 67 (6): 1173-80.

5. Mucci LA, Hjelmborg JB, Harris JR, et al. Familial risk and heritability of cancer among twins in Nordic countries. JAMA 2016; 315 (1): 68-76.

6. Harris J, Budin-Ljøsne I, Haugan A (Guest editors). Biobanking: From vision to reality. Norsk Epidemiologi 2012; 21 (2).

7. Næss O, Søgaard AJ, Arnesen E, et al. Cohort profile: cohort of Norway (CONOR). Int J Epidemiol 2008; 37 (3): 481-5.

8. Magnus P, Birke C, Vejrup K, et al. Cohort Profile Update: The Norwegian Mother and Child Cohort Study (MoBa). Int J Epidemiol 2016; 45 (2): 382-8.

9. Krokstad S, Langhammer A, Hveem K, et al. Cohort Profile: the HUNT Study, Norway. Int J Epidemiol 2013; 42 (4): 968-77.

10. Jacobsen BK, Eggen AE, Mathiesen EB, Wilsgaard T, Njølstad I. Cohort profile: the Tromsø Study. Int J Epidemiol 2012; 41 (4): 961-7.

11. Zhang G, Feenstra B, Bacelis J, et al. Genetic associations with gestational duration and spontaneous preterm birth. N Engl J Med 2017, doi:10.1056/NEJMoa1612665.

12. Graner S, Svensson T, Beau AB, et al. Neuraminidase inhibitors during pregnancy and risk of adverse neonatal outcomes and congenital malformations: population based European register study. BMJ 2017; 356: j629.

13. Ebbing C, Kiserud T, Johnsen SL, Albrechtsen S, Rasmussen S. Prevalence, risk factors and outcomes of velamentous and marginal cord insertions: a population-based study of 634,741 pregnancies. PloS One 2013; 8 (7): e 70380.

14. Ebbing C, Johnsen SL, Albrechtsen S, Sunde ID, Vekseth C, Rasmussen S. Velamentous or marginal cord insertion and the risk of spontaneous preterm birth, prelabor rupture of the membranes, and anomalous cord length, a population-based study. Acta Obstet Gynecol Scand 2017; 96 (1): 78-85.

15. Berg E, Haaland OA, Feragen KB, et al. Health status among adults born with an oral cleft in norway. JAMA Pediatr 2016; 170 (11): 1063-70.

16. Reigstad MM, Larsen IK, Myklebust TA, et al. Risk of cancer in children conceived by assisted reproductive technology. Pediatrics 2016; 137 (3): e20152061.

17. Swamy GK, Østbye T, Skjærven R. Association of preterm birth with long-term survival, reproduction, and next-generation preterm birth. JAMA 2008; 299 (12): 1429-36.

18. Klitkou ST, Iversen T, Stensvold HJ, Rønnestad A. Use of hospital-based health care services among children aged 1 through 9 years who were born very preterm - a population-based study. BMC Health Services Research 2017; 17 (1): 571. 
19. Engeland A, Bjørge T, Klungsøyr K, Skurtveit S, Furu K. Preterm births and use of medication in early adulthood: a population-based registry study. Pharmacoepidemiol Drug Safety 2017; 26 (7): 742-51.

20. Riise ØR, Laake I, Vestrheim D, et al. Risk of pertussis in relation to degree of prematurity in children less than 2 years of age. Pediatr Infect Dis J 2017; 36 (5): e151-e6.

21. Sundh KJ, Henningsen AK, Kallen K, et al. Cancer in children and young adults born after assisted reproductive technology: a Nordic cohort study from the Committee of Nordic ART and Safety (CoNARTaS). Hum Reprod 2014; 29 (9): 2050-7.

22. Lie RT, Wilcox AJ, Skjærven R. Survival and reproduction among males with birth defects and risk of recurrence in their children. JAMA 2001; 285 (6): 755-60.

23. Reigstad MM, Storeng R, Myklebust TA, et al. Cancer risk in women treated with fertility drugs according to parity status - a registry-based cohort study. Cancer Epidemiol Biomarkers Prev 2017; 26 (6): 953-62.

24. Ananth CV, Skjaerven R, Klunssoyr K. Change in paternity, risk of placental abruption and confounding by birth interval: a population-based prospective cohort study in Norway, 1967-2009. BMJ Open 2015; 5 (2): e007023.

25. Vatten LJ, Skjærven R. Effects on pregnancy outcome of changing partner between first two births: prospective population study. BMJ 2003; 327 (7424): 1138.

26. Vatten LJ, Skjærven R. Skifte av partner mellom fødsler og uheldig svangerskapsutfall. Tidsskr Nor Legeforen 2003; 123 (24): 3546-8.

27. Riise HK, Sulo G, Tell GS, et al. Incident coronary heart disease after preeclampsia: role of reduced fetal growth, preterm delivery, and parity. J Am Heart Assoc 2017; 6 (3).

28. Morken NH, Halland F, DeRoo LA, Wilcox AJ, Skjærven R. Offspring birthweight by gestational age and parental cardiovascular mortality: a population-based cohort study. BJOG 2017, doi: 10.1111/1471-0528.14522.

29. Charlton RA, Klungsøyr K, Neville AJ, et al. Prescribing of antidiabetic medicines before, during and after pregnancy: a study in seven european regions. PloS One 2016; 11 (5): e0155737.

30. Garne E, Vinkel Hansen A, Morris J, et al. Risk of congenital anomalies after exposure to asthma medication in the first trimester of pregnancy - a cohort linkage study. BJOG 2016; 123 (10): 1609-18.

31. Makela KT, Matilainen M, Pulkkinen P, et al. Failure rate of cemented and uncemented total hip replacements: register study of combined Nordic database of four nations. BMJ 2014; 348: f7592.

32. Sankila R, Olsen JH, Anderson H, et al. Risk of cancer among offspring of childhood-cancer survivors. Association of the Nordic Cancer Registries and the Nordic Society of Paediatric Haematology and Oncology. N Engl J Med 1998; 338 (19): 1339-44.

33. Brodwall K, Greve G, Leirgul E, Tell GS, Vollset SE, Øyen N. Recurrence of congenital heart defects among siblings - a nationwide study. Am J Med Genet [A] 2017; 173 (6): 1575-85.

34. Eriksen W, Sundet JM, Tambs K. Birth weight and the risk of overweight in young men born at term. Am J Hum Biol 2015; 27 (4): 564-9.

35. Kristensen P, Keyes KM, Susser E, Corbett K, Mehlum IS, Irgens LM. High birth weight and perinatal mortality among siblings: A register based study in Norway, 1967-2011. PloS One 2017; 12 (2): e 0172891.

36. Risnes KR, Pape K, Bjørngaard JH, Moster D, Bracken MB, Romundstad PR. Premature adult death in individuals born preterm: a sibling comparison in a prospective nationwide follow-up study. PloS One 2016; 11 (11): e0165051.

37. Ruggajo P, Skrunes R, Svarstad E, Skjærven R, Reisæther AV, Vikse BE. Familial factors, low birth weight, and development of ESRD: A nationwide registry study. Am J Kidney Dis 2016; 67 (4): 601-8.

38. Barker DJ. In utero programming of chronic disease. Clin Sci 1998; 95 (2): 115-28.

39. Silveira PP, Portella AK, Goldani MZ, Barbieri MA. Developmental origins of health and disease (DOHaD). J Pediatr (Rio J) 2007; 83 (6): 494-504.

40. Magnus MC, Olsen SF, Granstrom C, et al. Infant growth and risk of childhood-onset type 1 diabetes in children from 2 Scandinavian birth cohorts. JAMA Pediatr 2015; 169 (12): e153759.

41. Scholte RS, van den Berg GJ, Lindeboom M. Long-run effects of gestation during the Dutch Hunger Winter famine on labor market and hospitalization outcomes. J Health Econ 2015; 39: 17-30.

42. Barrett JR. Programming the future: Epigenetics in the context of DOHaD. Environ Health Perspect 2017; 125 (4): A72.

43. Magnus P. Looking for effects of environmental contaminants in a large birth cohort: Summarizing results of the Norwegian Mother and Child Cohort Study (MoBa). Int J Hyg Environ Health 2017; 220 (2 Pt A): 71-6.

44. Christoffersen T, Ahmed LA, Daltveit AK, et al. The influence of birth weight and length on bone mineral density and content in adolescence: The Tromsø Study, Fit Futures. Arch Osteoporos 2017; 12 (1): 54.

45. Borte S, Winsvold BS, Stensland SO, Smastuen MC, Zwart JA. The effect of foetal growth restriction on the development of migraine and tension-type headache in adulthood. The HUNT Study. PloS One 2017; 12 (4): e0175908. 
46. de Fine Licht S, Winther JF, Gudmundsdottir T, et al. Hospital contacts for endocrine disorders in Adult Life after Childhood Cancer in Scandinavia (ALiCCS): a population-based cohort study. Lancet 2014; 383 (9933): 1981-9.

47. Instanes JT, Halmøy A, Engeland A, Haavik J, Furu K, Klungsøyr K. Attention-deficit/hyperactivity disorder in offspring of mothers with inflammatory and immune system diseases. Biol Psychiatry 2017; 81 (5): $452-9$.

48. Grøtvedt L, Kvalvik LG, Grøholt EK, Akerkar R, Egeland GM. Development of social and demographic differences in maternal smoking between 1999 and 2014 in Norway. Nicotine Tob Res 2017; 19 (5): 539-46.

49. Oftedal AM, Busterud K, Irgens LM, Haug K, Rasmussen S. Socio-economic risk factors for preterm birth in Norway 1999-2009. Scand J Public Health 2016; 44 (6): 587-92.

50. Eskild A, Herdlevør IE, Strøm-Roum EM, Monkerud L, Grytten J. Childbirth or termination of pregnancy: does paid employment matter? A population study of women in reproductive age in Norway. Acta Obstet Gynecol Scand 2016; 95 (5): 513-8.

51. Halland F, Morken NH, DeRoo LA, Klungsøyr K, Wilcox AJ, Skjærven R. Association of women's reproductive history with long-term mortality and effect of socioeconomic factors. Obstet Gynecol $2015 ; 126$ (6): 1181-7.

52. Karlstad Ø, Furu K, Stoltenberg C, Håberg SE, Bakken IJ. ADHD treatment and diagnosis in relation to children's birth month: Nationwide cohort study from Norway. Scand J Public Health 2017; 45 (4): 343-9.

53. Bakken KS, Skjeldal OH, Stray-Pedersen B. Higher risk for adverse obstetric outcomes among immigrants of African and Asian descent: a comparison study at a low-risk maternity hospital in Norway. Birth 2015; 42(2): $132-40$.

54. Hellevik S. Feil diagnosekoder gir dårligere styring av helseforetakene. Tidsskr Nor Legeforen 2017, doi: 10.4045/tidsskr.17.0428.

55. Riksrevisjonen. Riksrevisjonens undersøkelse av medisinsk kodepraksis i helseforetakene. Dokument 3:5 (2016-2017). ISBN 978-82-8229-383-9.

56. Lehmann S, Baghestan E, Bordahl P, Ebbing M, Irgens L, Rasmussen S. Validation of data in the Medical Birth Registry of Norway on delivery after a previous cesarean section. Acta Obstet Gynecol Scand $2017 ; 96$ (7): 892-7.

57. Klungsøyr K, Harmon QE, Skard LB, et al. Validity of pre-eclampsia registration in the Medical Birth Registry of Norway for women participating in the Norwegian Mother and Child Cohort Study, 1999-2010. Paediatr Perinat Epidemiol 2014; 28 (5): 362-71.

58. Sunde ID, Vekseth C, Rasmussen S, Mahjoob E, Collett K, Ebbing C. Placenta, cord and membranes: a dual center validation study of midwives' classifications and notifications to the Medical Birth Registry of Norway. Acta Obstet Gynecol Scand 2017; 96 (9): 1120-7.

59. Moth FN, Sebastian TR, Horn J, Rich-Edwards J, Romundstad PR, Åsvold BO. Validity of a selection of pregnancy complications in the Medical Birth Registry of Norway. Acta Obstet Gynecol Scand 2016; 95 (5): 519-27.

60. Ludvigsson JF, Håberg SE, Knudsen GP, et al. Ethical aspects of registry-based research in the Nordic countries. Clin Epidemiol 2015; 7: 491-508.

61. Emberland KE, Rørtveit G. Norske helsedata - en utilgjengelig skatt. Tidsskr Nor Legeforen $2016 ; 136$ (18): 1506.

62. Maret-Ouda J, Tao W, Wahlin K, Lagergren J. Nordic registry-based cohort studies: Possibilities and pitfalls when combining Nordic registry data. Scand J Public Health 2017; 45 (17 suppl): 14-9.

63. Helse- og omsorgsdepartementet. Helsedatautvalget. Høring av rapport fra Helsedatautvalget: Et nytt system for enklere og sikrere tilgang til helsedata. 2017. https://www.regjeringen.no/no/dokumenter/horing-avrapport-fra-helsedatautvalget-et-nytt-system-for-enklere-og-sikrere-tilgang-til-helsedata/id2569090/.

64. Andreassen OA. eHealth provides a novel opportunity to exploit the advantages of the Nordic countries in psychiatric genetic research, building on the public health care system, biobanks, and registries. Am J Med Genet [B] 2017, doi: 10.1002/ajmg.b.32561.

65. Direktoratet for eHelse. Helsedataprogrammet 2017. https://ehelse.no/helsedataprogrammet. 